\title{
ENGINEERING AND GEODESIC RESEARCH OF VERTICAL DISPLACEMENTS OF BUILDINGS AND STRUCTURES ON THE TERRITORY OF PIDHORETSKYI MONASTERY
}

\author{
ІНЖЕНЕРНО-ГЕОДЕЗИЧНІ ДОСЛІДЖЕННЯ \\ ВЕРТИКАЛЬНИХ ЗМІЩЕНЬ БУДІВЕЛЬ ТА СПОРУД \\ НА ТЕРИТОРІЇ ПІДГОРЕЦЬКОГО МОНАСТИРЯ
}

\author{
Olena Kubrak ${ }^{1}$ \\ Andrij Balian ${ }^{2}$ \\ Oksana Serant ${ }^{3}$
}

DOI: https://doi.org/10.30525/978-9934-26-049-0-32

Abstract. The aim of the study is to observe the dynamics of soil movement and deformation of the complex of buildings and structures in the Pidhoretskyi monastery on the basis of geodetic measurements in complex engineering and geological conditions in the protected area, as well as permanent monitoring of vertical displacements for analysis and further recommendations for concerning safe operation of engineering constructions. Due to significant landslides on the slopes of the terrace, the buildings and structures of the Pidhoretskyi monastery are in a state of emergency. To save the architectural monument of the 18th century, which is located on the territory of Plisnetskyi reserve, a reference geodetic planned-height network (proving ground) has been created, which allows to determine the magnitude and direction of soil landslides; to determine the deformation of buildings and structures; to determine the amount of subsidence of structures as well as monitoring these processes. The support network consists of 2 planned-height (source) soil geodetic points for control of six stationary observation stations, 4 of which are located on one top of the mountain slope, and 2 are on the other. The height basis is

\footnotetext{
${ }^{1}$ Candidate of Technical Sciences, Senior Lecturer at Department of Geodesy, Lviv Polytechnic National University, Ukraine

${ }^{2}$ Assistant at Department of Geodesy,

Lviv Polytechnic National University, Ukraine

${ }^{3}$ Candidate of Technical Sciences, Senior Lecturer at Department of Geodesy,

Lviv Polytechnic National University, Ukraine
} 
created by leveling of the II class. Planned-height network consists of eight lines: some are designed and laid parallel to the church buildings, others are directed towards the ravines to determine the dynamics of their movement. A total of 87 reinforcing marks for linear - angular observations are laid. To observe the deformations of buildings and structures, 35 external wall signs (benchmarks) were laid in the foundations of the buildings, 20 were laid in the retaining wall and 22 internal signs (dowels) were laid in the stone floor of the church. The total number of all wall signs are 77 . We proposed the manufacture of polymer poles on the ground from the polymer pipes, with which we fixed all points of the planned height network. The convenience of their use is due to the fact that they meet the requirements of the instructions and they can be used in the territories of cultural heritage sites of national importance, without violating the Law of Ukraine. Centers can be made from improvised materials quickly and conveniently; their cost is quite low; ease and forced centering of devices and reflectors above the signs eliminates centering errors. Research methods. Geometric leveling of the second class with Ni-002 level and observation of displacements in the targets was performed at the proving ground. Research results. For the first time on the territory of Pidhoretskyi monastery a stationary geodetic proving ground was created for permanent observations of soil movements, deformations of buildings and structures. The points of the proving ground are laid down by the proposed types of centers. On the basis of geodetic observations, uneven and uniform subsidence of the marks of the studied buildings and structures, displacement of points of alignment were determined; maps of vertical movements of the earth's surface of the territory of the Pidhoretskyi monastery were created.

\section{1. Вступ}

Предметом досліджень є територія, будівлі та споруди Підгорецького монастиря, які зазнають деформації та руйнування внаслідок впливу зовнішнього середовища. Монастир розташований у Бродівському районі Львівської області на території Плісненського городища, яке знаходиться у складному, в морфологічному відношенні, районі, а саме - на вершині відокремленого глибокими ярами і балками плато, на висоті від 300 до 400 м над рівнем моря та $є$ пам'яткою архітектури XVIII ст. Проведена геологічна розвідка виявила наявність у геологіч- 
ному розрізі схилу водотривкі глини. У багатьох місцях, води водоносних горизонтів розвантажуються у вигляді численних джерел. Такі джерела розташовані північно-східніше церкви: одне на віддалі 5 м від неї, інше 35 м. Друге джерело каптоване, над ним збудована капличка. Вода 3 джерела трубою надходить до водозбірника, частина подається до водонапірної башти, інша скидається у штучний став. Дебіт цього джерела сягає 3,5-4,0 м $^{3}$ за годину. Третє джерело знаходиться ліворуч від в'їзної брами.

Джерело, що розташоване безпосередньо біля монастирської церкви утворює на поверхні землі мочарі. Частина води, що тут накопичується спеціально влаштованим жолобом, відводиться від церкви, але скидається безпосередньо на схил у напрямі пониження рельєфу. Частина грунтових вод розвантажується у штучний став.

Внаслідок неконтрольованих насипів на схил техногенних грунтів у багатьох місцях були перекриті джерела, це зумовило неможливість природного розвантаження, що викликало додаткове зволоження порід на схилі.

Водоносний горизонт у зсувних відкладах характеризується вкрай нестабільним режимом. Внаслідок прояву декількох фаз зсувного процесу, частково або повністю були перекриті шляхи міграції вод, що привело до інтенсивного зволоження порід у межах зсувного тіла. На ділянках, де утворилися досить високі (до 2 м) схили зсувних терас, виникли умови для вільного виходу і розвантаження грунтових вод 3 утворенням струмків.

У східній частині схилу грунтові води дренуються вододілом. Струмки, що протікають вздовж схилу, призвели до його ерозії. Через розмивання грунтів утворилися досить глибокі (до 1 м і більше) вимоїни, які сприяють зміщенню порід.

У результаті це привело до аварійного стану пам'ятки архітектури. Для визначення величин зсувних явищ та деформацій, а також для розроблення програми методів їх запобігання, необхідно виконати комплекс досліджень та провести відповідні геодезичні роботи, а саме:

- визначити необхідну періодичність та створити відповідні методи для визначення вимірювання зсувів, осідань і деформацій;

- обгрунтувати та створити схеми планово-висотних мереж, а також програми геодезичних вимірів; 
- сконструювати та виготовити необхідні геодезичні знаки;

- визначити методи для перевірки положення знаків опорної мережі;

- закласти готові геодезичні знаки;

- виконати відповідні вимірювання для створення опорної мережі (тріан-гуляція, полігонометрія, геометричне нівелювання);

- виміряти: величини горизонтальних і вертикальних зміщень; величини крену і переносу споруди; розміри тріщин споруд .

Для виконання всіх перелічених завдань, створено опорну мережу, що складається 3 двох планово-висотних (вихідних) грунтових геодезичних пунктів для контролю за шістьма стаціонарними станціями спостережень, чотири з яких розташовані на одній вершині схилу гори, а два на іншій, з яких будуть виконуватися виміри щодо зсувів грунтів схилів та тераси. Висотну основу створено нівелюванням II класу. Планово-висотна мережа складається 3

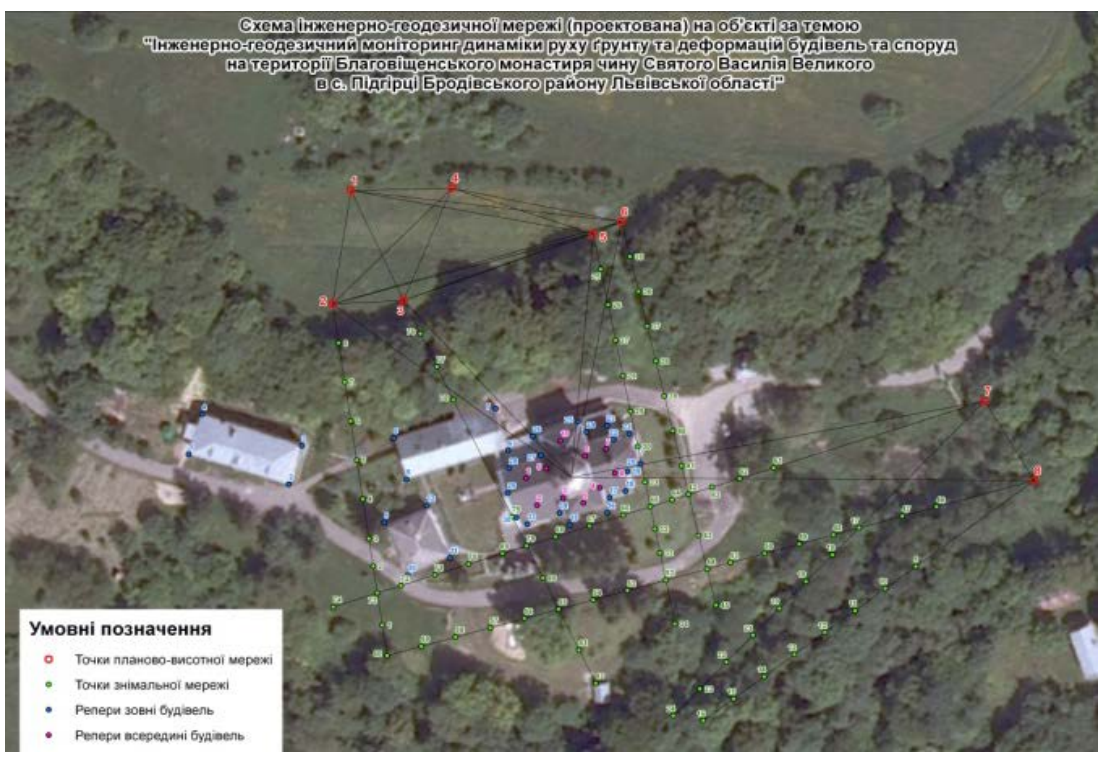

Рис. 1. Схема інженерно-геодезичної мережі на території Підгорецького монастиря 
восьми створів: одні запроектовані і закладені паралельно до будівель церкви, інші - направлені в сторону ярів для визначення динаміки їх руху. Всього у створах закладено 87 арматурних знаків для лінійно-кутових спостережень. Для спостережень за деформаціями будівель та споруд закладено 35 зовнішніх стінних знаків (реперів) в фундаменти споруд, 20 - у підпірну стінку та 22 внутрішніх знаки (дюбелі) в кам'яну підлогу церкви. Загальна кількість всіх стінних знаків - 77 шт. (рис. 1) [1, с. 63].

\section{2. Особливості виготовлення та закладання центрів пунктів гео-дезичної мережі}

Постановою Кабінету Міністрів України № 928 від 3 вересня 2009 р. територію Підгорецького монастиря занесено до Державного реєстру нерухомих пам'яток України. Рішенням XXXV сесії VI-го скликання Львівської обласної ради від 15 вересня 2015 р. (№ 1449) було створено «Історико-культурний заповідник «Давній Пліснеськ». Тому під час закладання пунктів геодезичної основи виникли складнощі. Вони пов'язані з тим, що відповідно до п. 4 ст. 33 Закону України «Про охорону культурної спадщини» [5] на охоронних археологічних територіях забороняється проводити будь-які земляні роботи без дозволу відповідного органу охорони культурної спадщини. Всі місця закладки знаків погоджувались із адміністрацією заповідника «Давній Пліснеськ» та відбувалися під наглядом представників названої організації.

Проаналізувавши сучасні публікації [2, с. 117; 7, с. 142; 9; 10], з'ясувалося, що виробники геодезичного обладнання пропонують використання нових видів центрів геодезичних пунктів, які виготовляють зі стиснутого полімербетону, алюмінію, пластику тощо. Такі види центрів не підходять для нашої заповідної території.

Нами запропоновано виготовлення відразу на місцевості пілонів центрів із полімерних труб, якими ми закріпили всі пункти планововисотної мережі.

Створений геодезичний полігон буде стаціонарним (постійним) для спостережень за рухами грунтів і деформаціями будівлі, тому для зручності і точності спостережень розроблені відповідні конструкції центрів. 


\section{1. Опис центра стаціонарної спостережної станції}

На стаціонарних станціях, було закладено центри, основними деталями яких є пластикова труба діаметром 160 мм, довжиною 3000 мм, яка заповнюється бетоном (рис. 2).

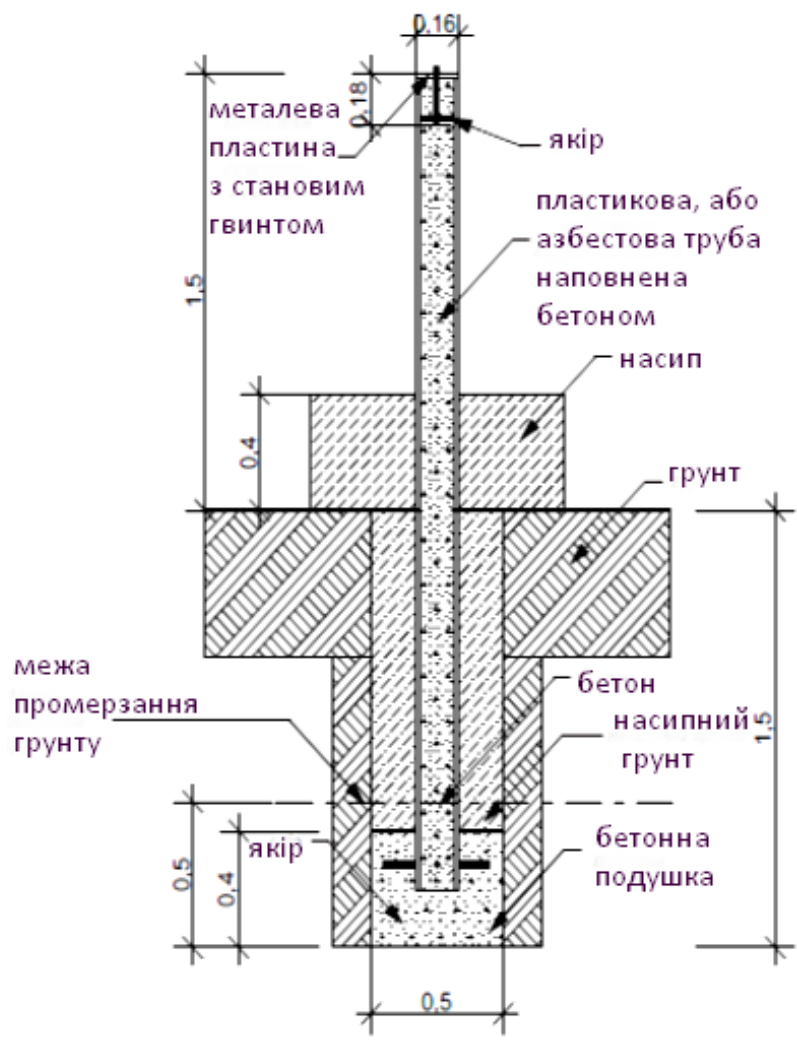

\section{Рис. 2. Схема центра пункту опорної планово-висотної основи}

Довжина знаку обумовлена тим, що його закладають нижче глибин и промерзання грунту $(0,5$ м), а також висотою встановлення приладу (1,5 м). Для забезпечення стійкості пілона низ труби зафіксований двома перехресними металевими стержнями (якорями) довжиною 40 см, діаметром 12-14 мм на віддалі 10-15 см від нижнього 
краю труби і вставлений у закладену «бетонну подушку» товщиною 20-25 см. Від бетонної подушки до поверхні землі яму засипали грунтом 3 поступовим трамбуванням [8, с. 91].

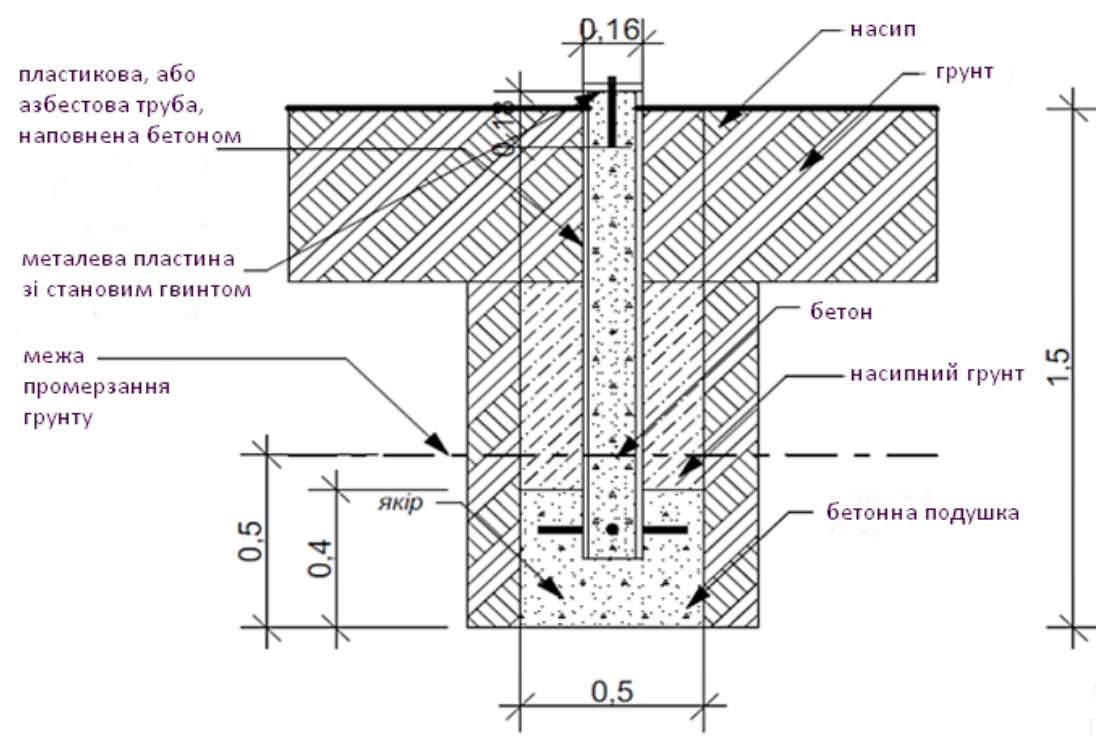

Рис. 3. Схема центра стаціонарної спостережної станції

\section{2. Опис центра пункту опорної (вихідної)}

\section{планово-висотної основи}

Ці центри одночасно є висотними реперами і пунктами планової основи. Їх виготовляли та закладали безпосередньо на місці також із підручних матеріалів. Основою знаку теж є пластикова труба діаметром 160 мм, довжиною 1500 мм, яка заповнюється бетоном (рис. 3). Довжина труби вибрана з огляду на те, що репер повинен закладатися нижче глибини промерзання грунтів $(0,5$ м), а верхня його частина має бути в рівень поверхні землі, щоб мінімізувати вплив механічних пошкоджень та погодних умов. Металевий якір (штир) довжиною 40 см, товщиною 20-26 мм із привареними навхрест металевими стержнями в нижній частині довжиною 100-120 мм закладався в бетон. У верхню частину пілона центра закладено металевий стержень, зато- 
чений напівсферичною формою з отвором в центрі для примусового центрування [8, с. 92].

Перевага використання таких центрів зумовлена тим, що вони відповідають вимогам інструкцій [5; 6] та їх можна використовувати на територіях об'єктів культурної спадщини національного значення, не порушуючи Закону України [4]. Центри можна виготовити з підручних матеріалів швидко і зручно; їх собівартість досить низька; легкість та примусове центрування приладів та відбивачів над знаками, що дозволяє виключити похибки центрування.

\section{3. Обгрунтування методів інженерно-геодезичних досліджень моніторингу зсувних процесів}

Інженерно-геодезичні спостереження за вертикальними зміщеннями виконували методом геометричного нівелювання. Його перевагами $є$ : висока точність і швидкість вимірювань; можливість використання недорогих приладів; виконання вимірювань в складних i обмежених умовах $[3 ; 6]$.

Вертикальні зміщення будівель, споруд та території монастиря були визначені, виконано нівелюванням II класу, воно відповідає вимогам точності. Відмітки деформаційних точок в циклі вимірювань визначали відносно опорного репера. За вихідний Rp (опорний грунтовий пункт) прийнято закладений репер № 1 з відомою відміткою.

Для передачі позначки від вихідного опорного грунтового пункту (Rp 1) на всі планово-висотні пункти та деформаційні знаки створів, а також для марок, закладених у фундаменти будівель та споруд розроблена схема нівелювання (рис. 4).

Визначення вертикальних зміщень будівель та споруд способом геометричного нівелювання, було виконано нівеліром NI 002 виробництва ГДР фірми Карл Цейс Єна та комплектом інварних рейок. Цей прилад відповідає вимогам, для виконання нівелювання I та II класів. Спостереження виконувалися за програмою нівелювання II класу згідно вимог Інструкції [6].

Навколо монастиря, для моніторингу вертикальних зміщень будівлі монастиря, господарських будівель, підпірної стінки та дослідження вертикальних рухів земної поверхні, заклали і розвинули висотну мережу у вигляді замкнених полігонів (рис. 4). Виконано п’ять циклів 


\section{Умовні позначення}

- Пункти висотної основи

- Пункти планово висотної основи

- Дерформаційні знаки

- Марки підпірної стінки

- Зовнішні марки

- Внутрішні марки монастиря

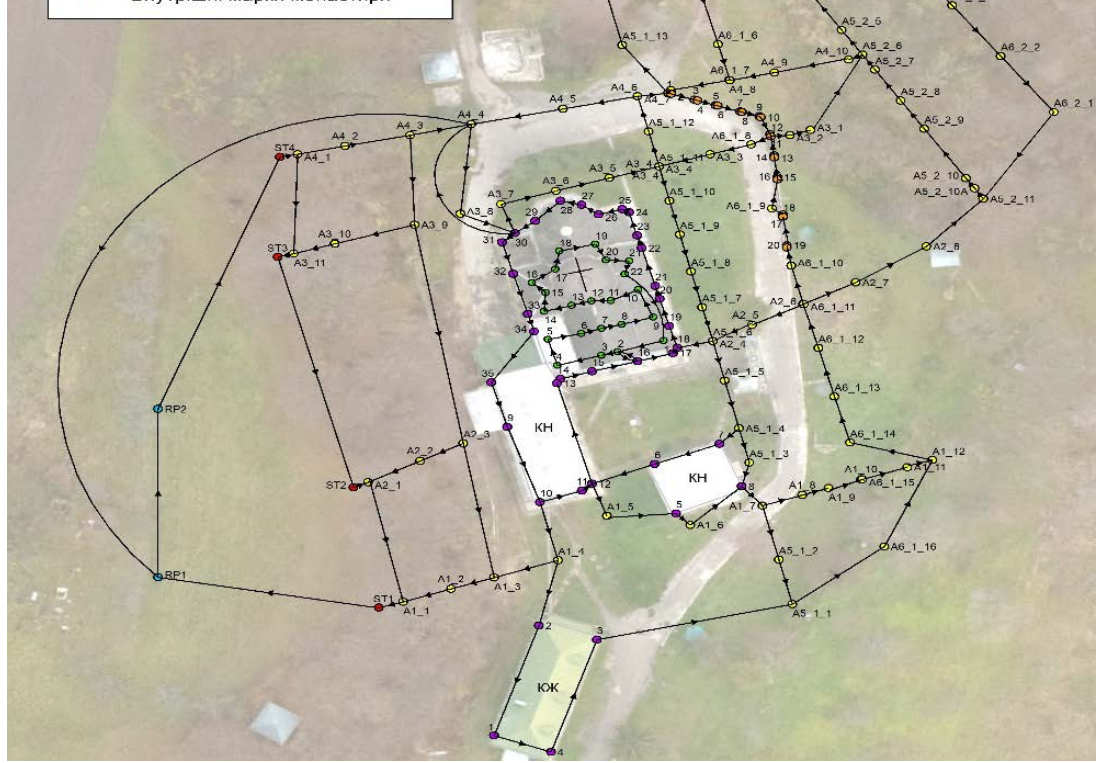

Рис. 4. Схема нівелірних ходів і розташування марок для спостережень за вертикальними зміщеннями будівель та деформаціями поверхні землі

вимірювань протягом року (листопад 2016 р., грудень 2016 р., квітень 2017 р., червень 2017 р., листопад 2017 р.) За результатами спостережень побудовано графік вертикальних рухів стаціонарних станцій спостережень (St1, St2, St3, St4, St5, St6) та Rp 2 відносно репера Rp 1 
(Графік 1). Для визначення вертикальних зміщень використовували однакову методику та схему вимірів. За вихідний пункт завжди приймався репер Rp 1.

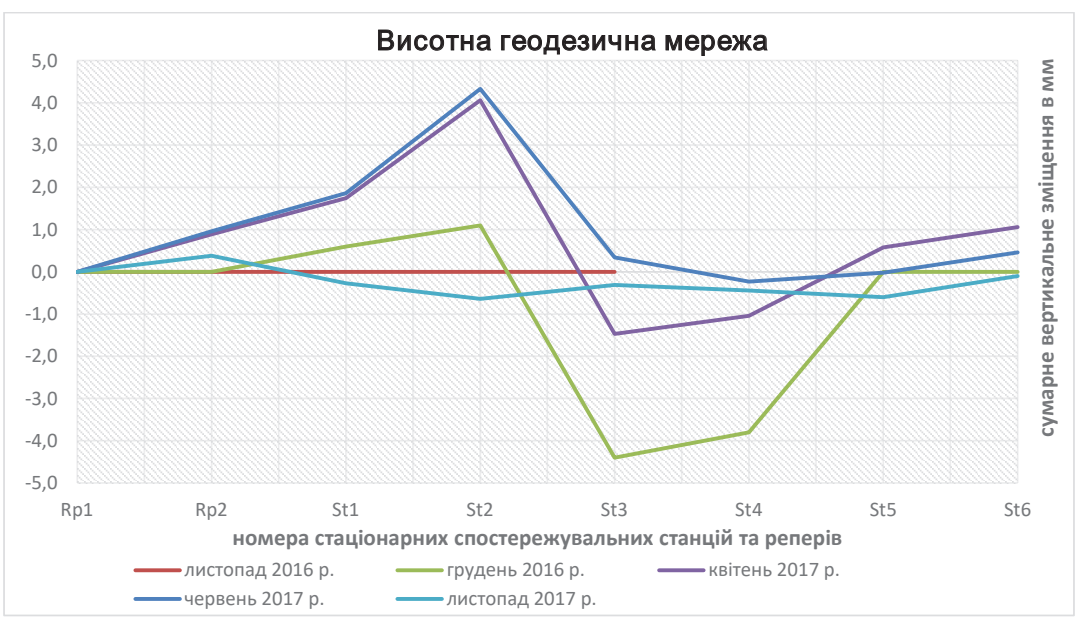

Графік 1. Графік сумарних вертикальних рухів стаціонарних спостережних станцій та реперів планово-висотної основи за п'ять серій спостережень

\section{4. Інженерно-геодезичний контроль вертикальних зміщень будівлі монастиря та господарських споруд}

Загалом, виконано 5 серій спостережень для контролю за вертикальними зміщеннями будівлі монастиря та господарськими спорудами. Схема розміщення деформаційних марок вказаних об'єктів приведена на рис. 4.

За опрацьованими результатами спостережень побудований графік вертикальних рухів деформаційних марок (Графік 2).

Максимальні вертикальні зміщення (Графік 2) деформаційних марок будівлі монастиря та господарських будівель мають наступні величини:

- станом на грудень 2016 р.: максимальне вертикальне зміщення знаходилось в межах від +0,4 мм до -0,8 мм;

- станом на квітень 2017 р.: максимальне вертикальне зміщення між серіями вимірів знаходилось в межах від $+2,8$ мм до 0 мм; сумарне 


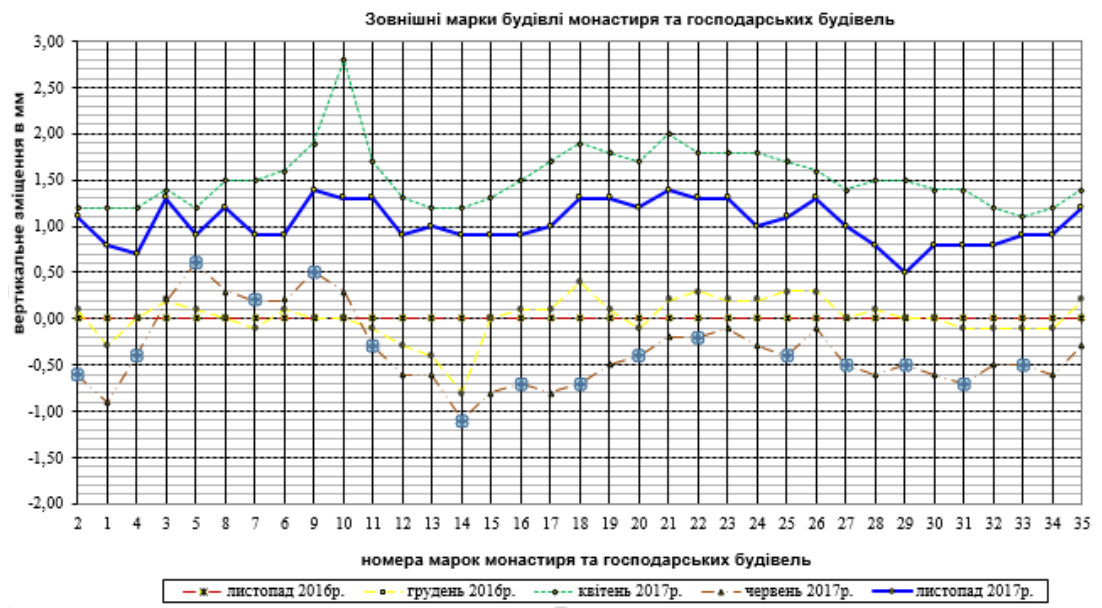

Графік 2. Графік вертикальних рухів марок монастиря та господарських будівель за п'ять серій спостереження

вертикальне зміщення за період листопад 2016 р. - квітень 2017 р. становить від $+2,8$ до 0 мм;

- станом на червень 2017 р.: максимальне вертикальне зміщення між серіями вимірів знаходилось в межах від $+0,8$ мм до -2,6 мм, сумарне вертикальне зміщення за період листопад 2016 р. - червень 2017 р. знаходилось в межах від +0,6 до -1,1 мм;

- станом на листопад 2017 р.: максимальне вертикальне зміщення між серіями вимірів знаходилось в межах від $+1,9$ мм до 0 мм, сумарне вертикальне зміщення за період листопад 2016 р. - листопад 2017 р. становить від $+1,4$ до 0 мм.

Як бачимо з приведених результатів вимірів величини вертикальних зміщень за вказані періоди мають сезонний коливальний характер, який обумовлений природніми факторами. Передача відмітки будівлі монастиря (марка № 30) виконана відносно Rp 1.

Максимальні вертикальні зміщення за виміряними перевищеннями між марками будівлі монастиря та господарських будівель відносно початкового виміру (листопад 2016 р.) мають наступні величини:

- станом на грудень 2016 р.: максимальне вертикальне зміщення знаходилось у межах від +0,30 мм до -0,24 мм; 
- станом на квітень 2017 р.: максимальне вертикальне зміщення становило від +0,39 мм до -0,41 мм;

- станом на червень 2017 р.: максимальне вертикальне зміщення знахо-дилась в межах від +0,32 мм до -0,42 мм;

- станом на листопад 2017 р.: максимальне вертикальне зміщення знаходилась в межах від +0,34 мм до -0,40 мм.

Із результатів вимірів, можна зробити висновок, що будівля монастиря та господарські будівлі не мають досить великого вертикального зміщення, ця величина змінюється в межам $\pm 0,42$ мм за рік, при допустимій величині до \pm 1 мм за рік.

Будівля монастиря та господарські будівлі відносно розвиненої висотної мережі мають сезонний коливальний рух, який обумовлений різними техногенними процесами. Проте, на нашу думку слід періодично продовжувати спостереження за вертикальними рухами будівлі монастиря та господарськими будівлями 3 метою попередження аварійного стану, бо період спостереження становив 1 рік, а циклічність вертикальних зміщень може бути коротшою.

\section{5. Інженерно-геодезичний контроль вертикальних зміщень марок підлоги будівлі монастиря}

Виконано 5 серій спостережень за вертикальними зміщеннями марок підлоги монастиря. Необхідність закладання деформаційних марок в підлогу монастиря була обумовлена тим, що підлога монастиря - це викладений настил з каменю і $є$ не горизонтальною, а з видимим поперечним та діагональним ухилом. Схема розміщення деформаційних марок в підлозі монастиря приведена на рис. 5, а опрацьовані результати вимірів показані на Графіку 3.

Згідно одержаних результатів, які приведені на Графік 3 максимальні величини вертикальних зміщень деформаційних марок підлоги будівлі монастиря мають наступні величини :

- станом на грудень 2016 р.: максимальне вертикальне зміщення знаходилось в межах від +0,5 мм до -0,1 мм;

- станом на квітень 2017 р.: максимальне вертикальне зміщення між серіями вимірів знаходилось в межах від $+1,9$ мм до 0 мм, сумарне вертикальне зміщення за період листопад 2016 р. - квітень 2017 р. становить від $+1,9$ до 0 мм; 


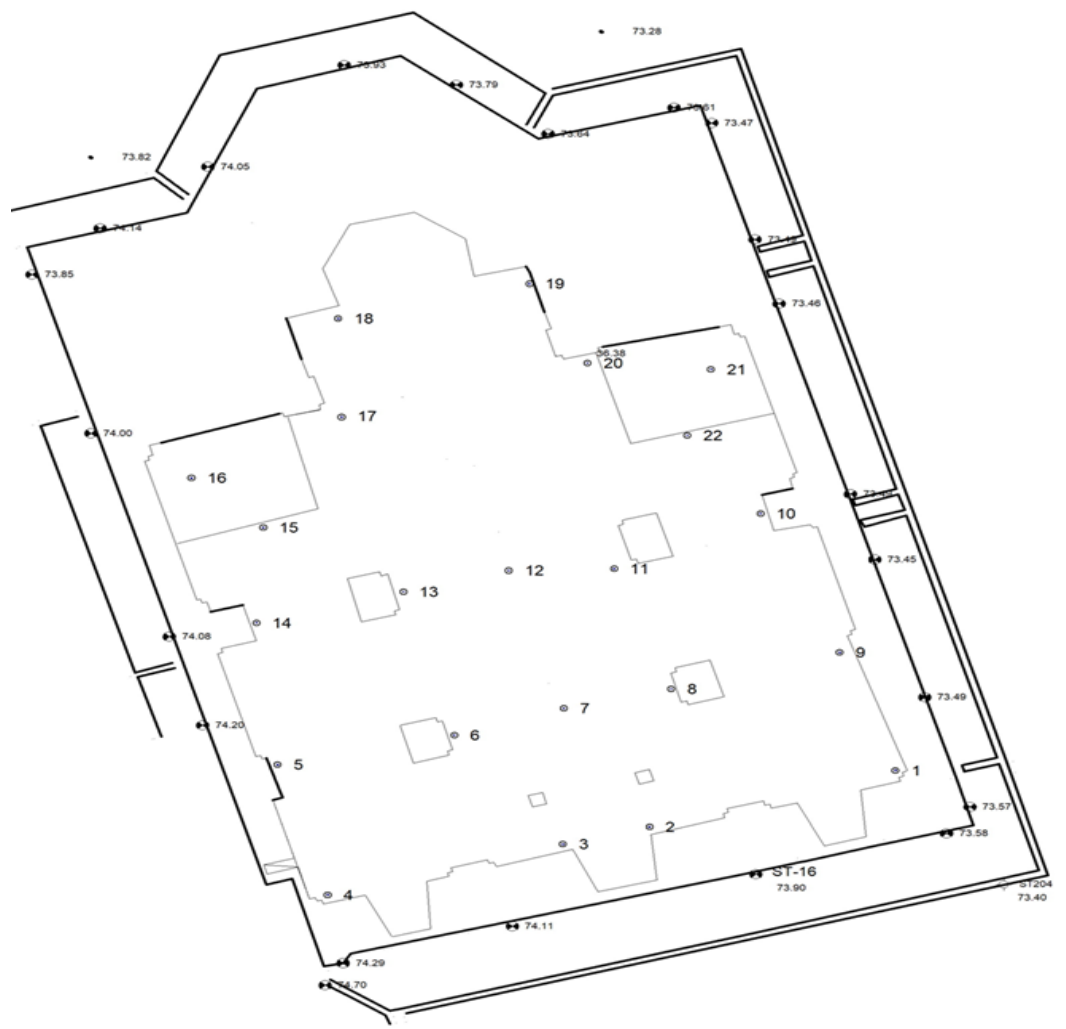

Рис. 5. Схема розміщення деформаційних марок у підлозі монастиря

- станом на червень 2017 р.: максимальне вертикальне зміщення між серіями вимірів знаходилось в межах від 0 мм до -2,3 мм, сумарне вертикальне зміщення за період листопад 2016 р. - червень 2017 р. становить від 0 мм до -0,6 мм;

- станом на листопад 2017 р.: максимальне вертикальне зміщення між серіями вимірів знаходилось в межах від +1,5 мм до 0 мм, сумарне вертикальне зміщення за період листопад 2016 р. - листопад 2017 р. становить від +1,2 до 0 мм. 


\section{Chapter «Engineering sciences»}

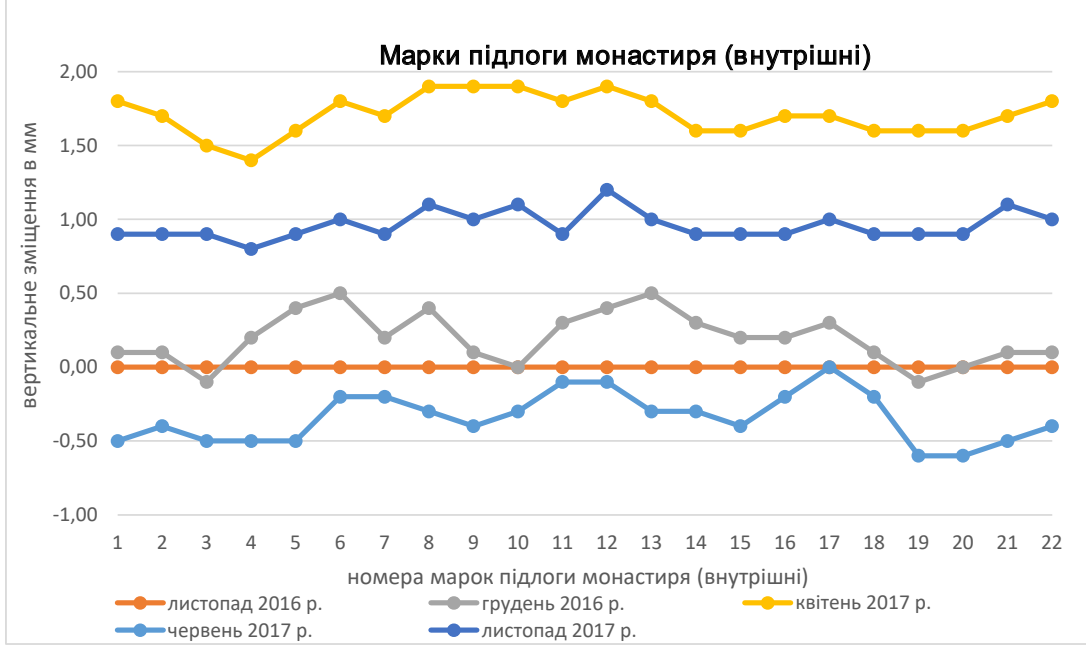

Графік 3. Графіки вертикальних рухів марок підлоги монастиря (внутрішніх) за п'ять серій спостереження

Наявність перекосу підлоги монастиря по ширині споруди і діагоналі підтвердилася. Найбільша різниця в перевищенні становить по діагоналі монастиря - різниця між крайніми марками становить 32 см. Проте, це не свідчить про аварійний стан будівлі. Слід згадати, що підлога монастиря встановлена $з$ каменю i, оскільки, немає даних про перекоси за минулі роки, то стверджувати про аварійність споруди не можна.

Отже, з результатів дослідження, видно, що вертикальні зміщення марок підлоги монастиря за рік знаходяться в межах $\pm 0,6$ мм при допуску \pm 1 мм. Наявні перекоси по ширині та діагоналях споруди за період дослідження знаходяться в межах допуску і носять коливальний характер. Тенденції щодо зростання величин перекосів за звітний період не виявлено. Рекомендовано для підтвердження припущень виконати повторні вимірювання.

\section{6. Інженерно-геодезичний контроль вертикальних зміщень підпірної стінки}

Підпірна стінка закладена між проїжджою частиною дороги та схилом тераси із використанням буронабивних паль, які об'єднані монолітним 
ростверком. Під час закладання марок в фундаменти будівель та створених деформаційних марок, звернули увагу на відслонення підпірної стінки від асфальтного покриття дороги, а також тріщини у ії верхній частині. Для спостережень за осіданням підпірної стінки було закладено 20 деформаційних марок у верхню їі частину. Виконано 5 серій спостереження за вертикальними зміщеннями марок підпірної стінки (листопад 2016 р., грудень 2016 р., квітень 2017 р., червень 2017 р. та листопад 2017 р.). Схема розміщення деформаційних марок підпірної стінки приведена на рис. 6 . За результатами опрацьованих вимірів побудовано графік 4.

Із виконаних спостережень видно, що марки підпірної стінки відносно закладеної висотної мережі, мають сезонний коливальний рух, який обумовлений різними техногенними процесами і становить від $-0,5$ до +5,0 мм. Прослідковується однакова величина підйому чи осі-

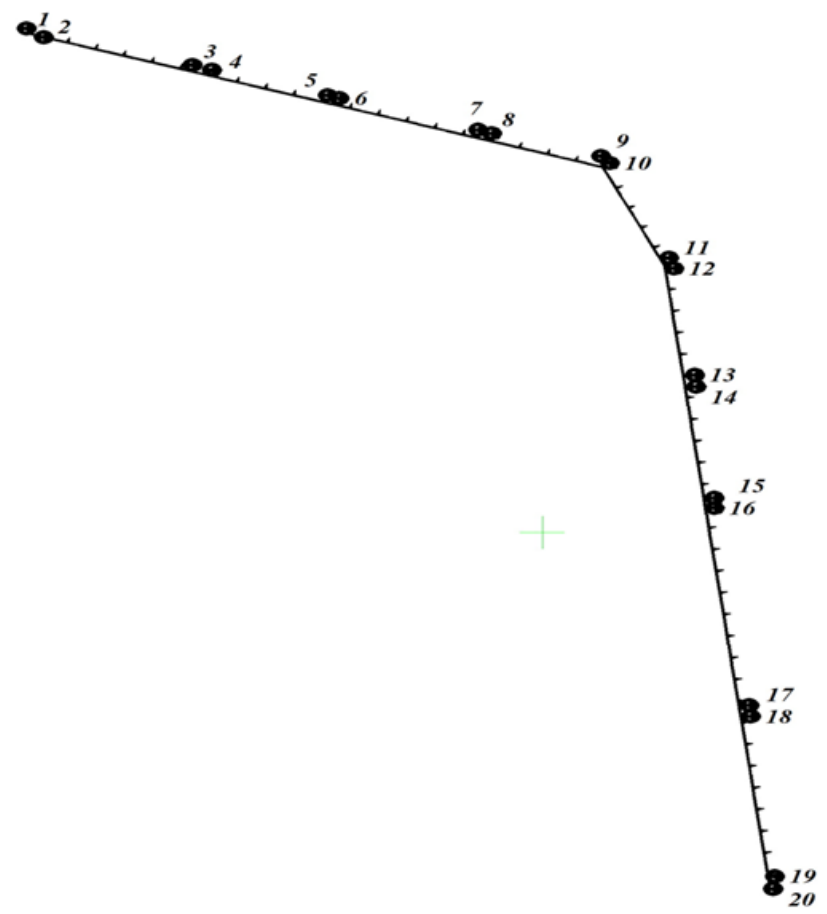

Рис. 6. Схема розміщення деформаційних марок на підпірній стінці 
дання всієї підпірної стінки між серіями вимірів. Процес вертикального руху видно з побудованого графіка вертикальних рухів марок підпірної стінки (Графік 4).

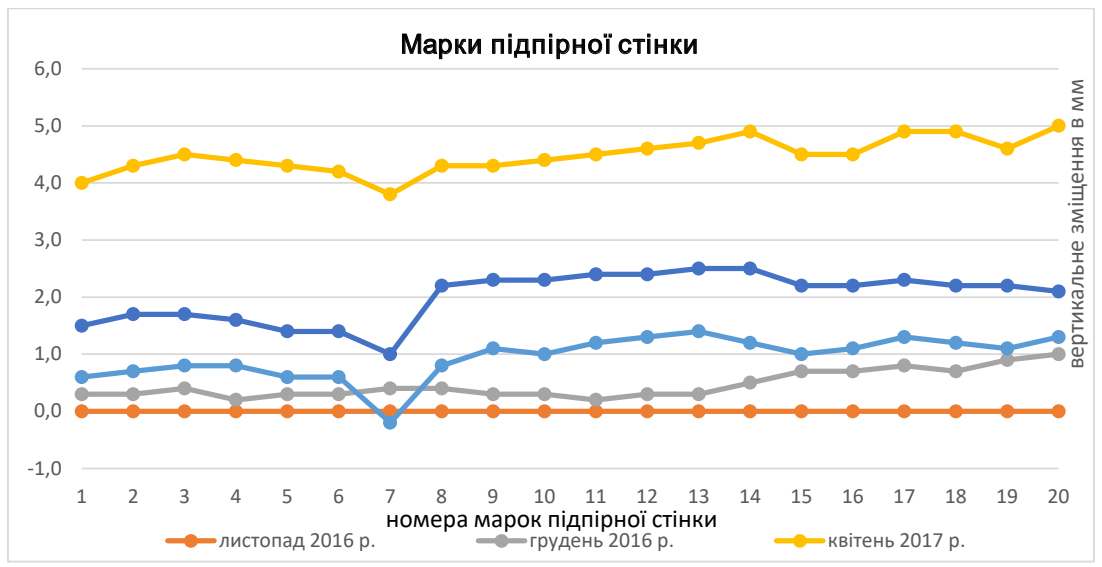

\section{Графік 4. Графік вертикальних рухів марок підпірної стінки за п'ять серій спостереження}

Згідно Графіка 4, марки підпірної стінки рівномірно піднімаються і опускаються, що свідчить про циклічність процесу. Виключенням $є$ зміщення марки № 7, яка відносно інших марок має менше підняття та залишається більш стабільною. Для підтвердження результатів було виконано порівняльний аналіз виміряних перевищень між серіями спостережень. Виміряні значення перевищень відносно початкового виміру змінювалися в межах $\pm 0,4$ мм, середньоквадратична помилка виміру одного перевищення на станції становить $\mu=0,27$ мм при допустимій величині для вибраного II класу нівелювання $\mu=0,40$ мм.

В результаті проведення 5 серій спостережень, встановлено, що марки підпірної стінки не мають значного вертикального зміщення, а його величина коливається в межам $\pm 0,41$ мм за рік. при допустимій до \pm 1 мм. Причиною відслонення підпірної стінки від асфальтного покриття проїжджої частини дороги може бути підмивання грунту під покриттям дороги грунтовими підземними водами, через неможливість стоку підземних, яким заважає підпірна стінка. Оскільки призна- 
чення підпірної стінки полягає в тому, щоб запобігати зсувам грунтів, то потрібно вести постійний моніторинг ії положення, а також пропонується зробити в стінці спеціальні отвори для відтоку води, з метою послаблення тиску води та захисту від подальшого ії відслонення.

\section{7. Інженерно-геодезичний контроль вертикальних зміщень створних деформаційних знаків}

Для визначення рухів земної поверхні навколо монастиря закладено 8 створів (рис. 7). Чотири створи розташовані по напрямку Пн-Пд, інші чотири - Сх-Зх. Загальна кількість деформаційних знаків в створах становить 88 штук.

Виконано 5 серій спостережень за вертикальними зміщеннями деформаційних знаків в створах (листопад 2016 р., грудень 2016 р., квітень 2017 р., червень 2017 р. та листопад 2017 р.). Для наочного відображення вертикального руху деформаційних знаків між серіями вимірів за опрацьованими вимірами побудовані графіки вертикальних рухів деформаційних знаків за звітні періоди спостережень 5, 6, 7, 8, 9, 10, 11, 12.

Згідно одержаних результатів, максимальні вертикальні зміщення деформаційних знаків створів відносно Rp 1:

- станом на грудень 2016 р.: вертикальне зміщення деформаційних знаків коливається в межах від +3,4 мм до -4,4 мм;

- станом на квітень 2017 р.: вертикальне зміщення деформаційних знаків між серіями вимірів коливається в межах від $+8,5$ мм до -4,1 мм, сумарне вертикальне зміщення за період листопад 2016 р. квітень 2017 р. становить від +8,6 мм до -4,5 мм;

- станом на червень 2017 р.: вертикальне зміщення деформаційних знаків між серіями вимірів знаходилось в межах від $+4,5$ мм до $-16,8$ мм, сумарне вертикальне зміщення за період листопад 2016 р. червень 2017 р. становить від +7,4 мм до -13,3 мм;

- станом на листопад 2017 р.: вертикальне зміщення деформаційних знаків між серіями вимірів знаходилось в межах від $+5,3$ мм до -13,7 мм, сумарне вертикальне зміщення за період листопад 2016 р. листопад 2017 р. є від $+4,7$ мм до $-13,7$ мм.

Одержані величини вертикальних зміщень за вказані періоди мають коливальний характер, який обумовлений зростанням величини вертикального руху та просіданням деформаційних знаків. 


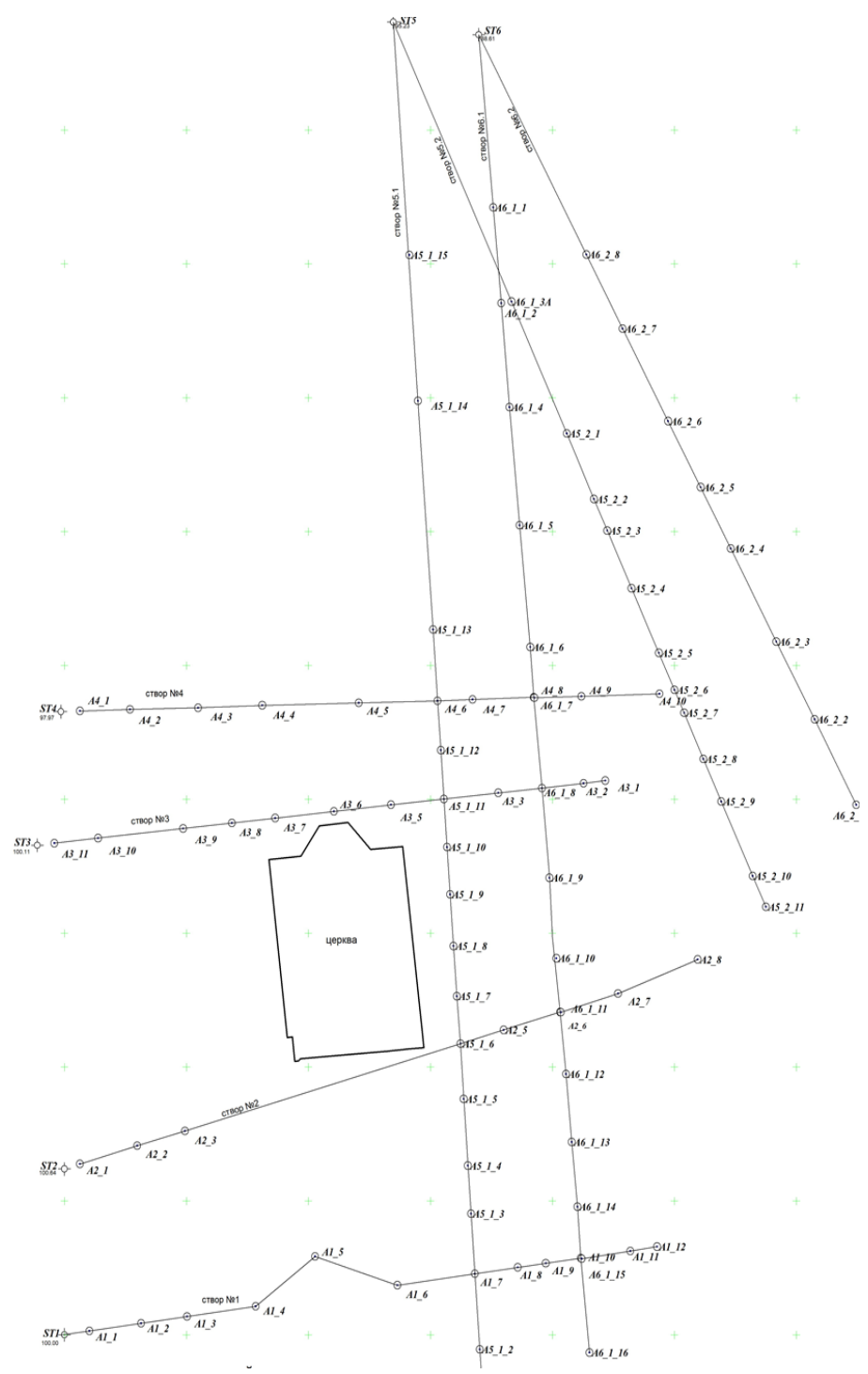

Рис. 7. Схема розміщення деформаційних знаків створів № 1, № 2, № 3, № 4, № 5.1, № 5.2, № 6.1, № 6.2 


\section{Olena Kubrak, Andrij Balian, Oksana Serant}
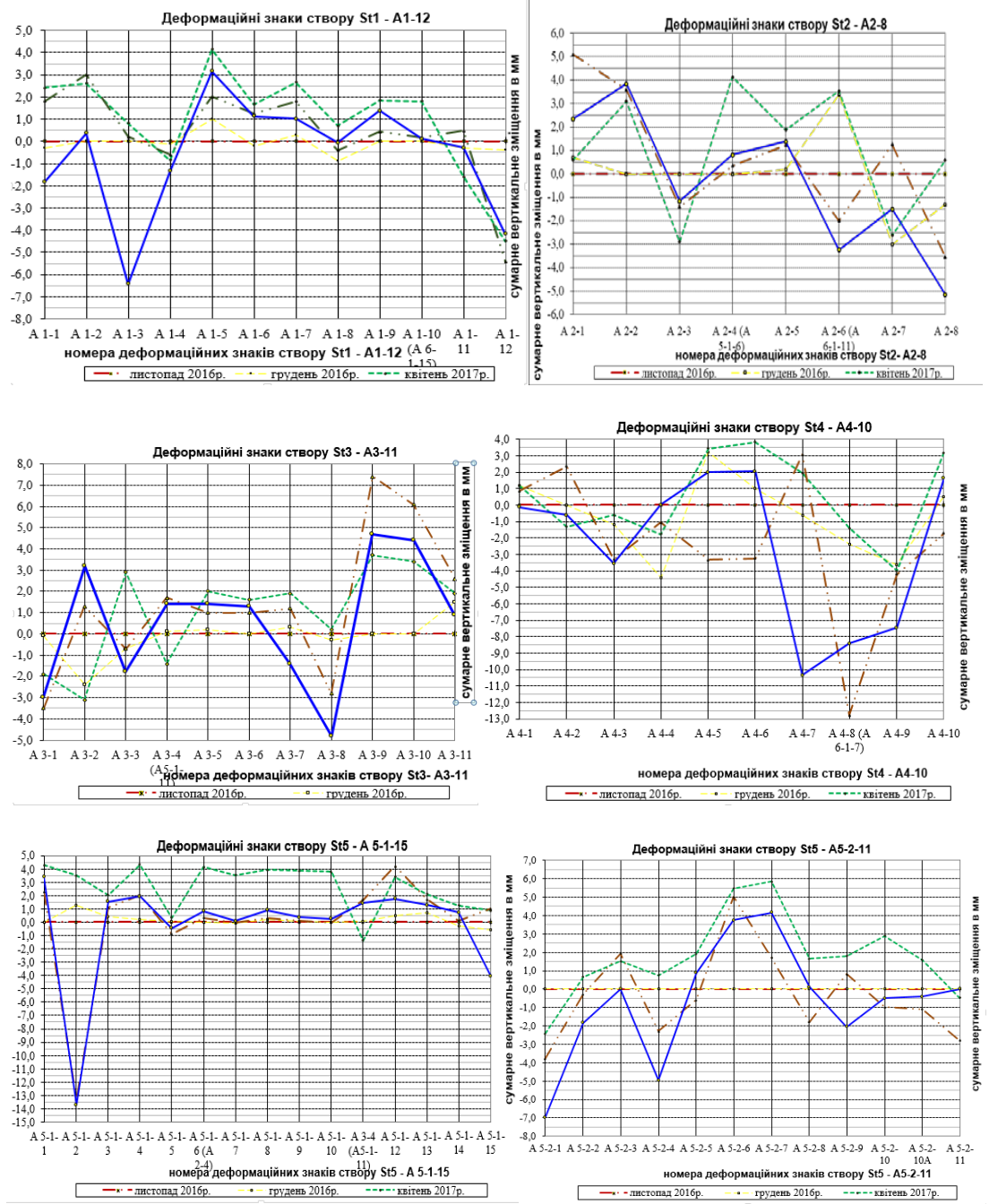

Графіки 5, 6, 7, 8, 9, 10, 11, 12. Графіки сумарних вертикальних рухів деформаційних знаків створів St1 - A1-12, St2 - A2-8, St3 - A3-11, St5 - A5-1-15, St4 - A4-10, St5 - A5-1-15, St5 - A5-2-11, St6 - A6-1-16, St6 - A6-2-8 за п'ять серій спостережень 
Chapter «Engineering sciences»

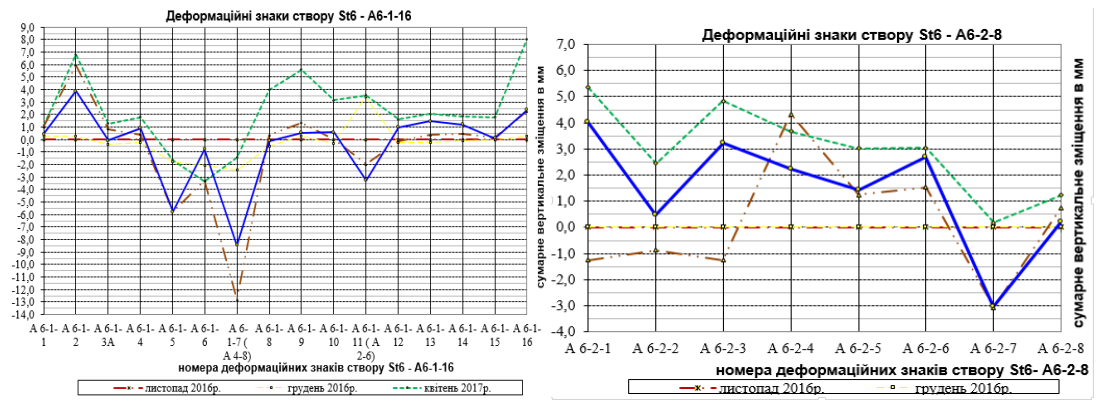

Графіки 11, 12

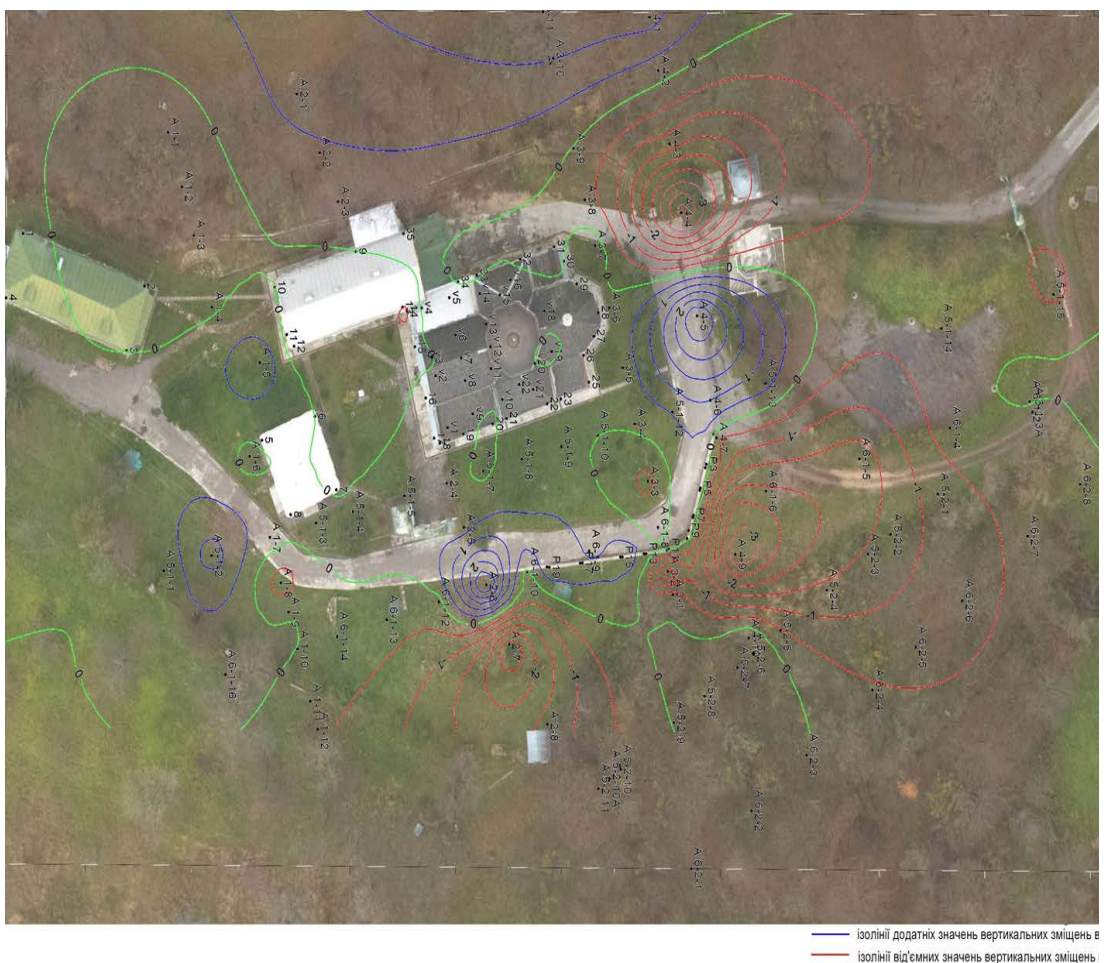

Рис. 8. Картосхема вертикальних рухів земної поверхні т-рії Підгорецького монастиря за даними вимірів листопад-грудень 2016 р. 
За даними вертикальних рухів деформаційних знаків 8-ми створів, а також даних вертикальних рухів деформаційних марок монастиря, господарських будівель та підпірної стінки відносно розвиненої висотної мережі, побудовано картосхеми вертикальних рухів земної поверхні на території Підгорецького монастиря (рис. 8, 9).

Деформаційні знаки на території Підгорецького монастиря є нестабільними (див. Графіки 5, 6, 7, 8, 9, 10, 11, 12, рис. 8, 9), тобто на даній території відбуваються деформаційні процеси. Вертикальні зміщення виявлено по всій дослідній ділянці навколо монастиря, але найбільші деформації земної поверхні в усіх серіях зосереджені в районі південного схилу тераси.

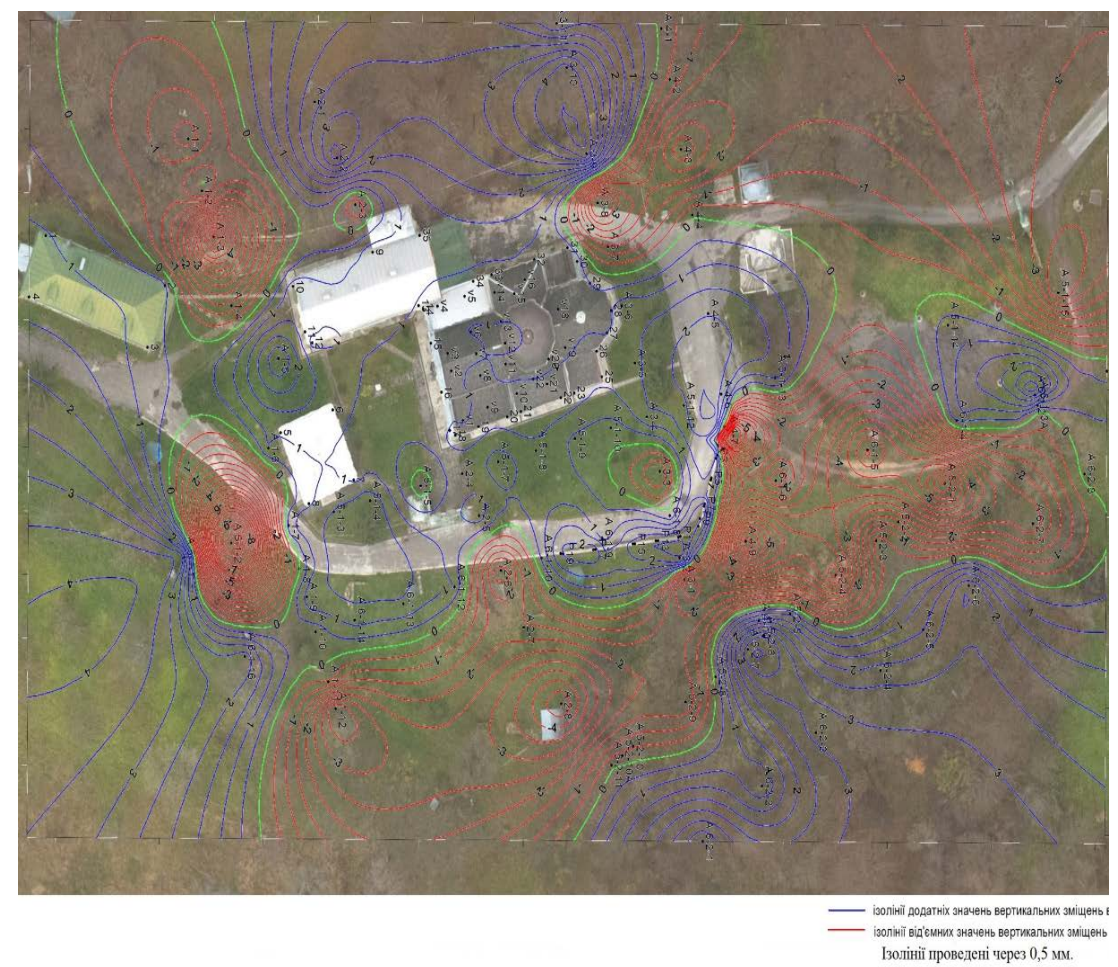

Рис. 9. Картосхема вертикальних рухів земної поверхні території Підгорецького монастиря за даними вимірів листопад 2016 р. - грудень 2017 р. 


\section{7. Висновки та рекомендації}

Виконано інженерно-геодезичний контроль вертикальних зміщень будівель, споруд та території Підгорецького монастиря. Зафіксовані величини вертикальних зміщень монастиря, господарських будівель та підпірної стінки знаходяться в межах допустимих значень та мають коливальний характер 3 невеликою тенденцією до іiі збільшення. Деформаційні знаки на території Підгорецького монастиря є нестабільними і свідчать про деформації земної поверхні.

3 метою запобігання аварійного стану будівлі монастиря, зсувів та обвалів необхідно продовжувати спостереження за вертикальними i горизонтальними рухами будівель та споруд на території монастиря, особливу увагу звернути на моніторинг підпірної стінки, звернувши увагу на контроль за її рухом в горизонтальному положенні.

Для більш детального аналізу щодо запобігання аварійного стану будівель та споруд, а також зсувних процесів території монастиря, рекомендовано провести:

- визначення та аналіз горизонтальних зміщень підпірної стінки;

- дослідження фізико-механічних властивостей грунтів як основи споруди;

- дослідження режимів грунтових вод;

- дослідження тиску під фундаментом;

- спостереження за змінами температури.

Рекомендується не рідше, як один раз на рік, проводити спостереження за описаною методикою, проконтролювати визначені величини вертикальних зміщень будівель і споруд та вертикальні деформації земної поверхні території монастиря.

\section{Список літератури:}

1. Ямелинець С., Приступа О., Балян А., Ямелинець А. Створення геодезичного полігону для планово-висотних спостережень за зсувами грунту i деформаціями будівель на території Підгорецького монастиря у Львівській області. Сучасні досягнення геодезичної науки та виробнищтва. 2017. Вип. I (33). С. 61-65.

2. Тревого І., Гур'єва М. Сучасні центри геодезичних пунктів. Сучасні досягнення геодезичної науки та виробнищтва. 2011. Вип. I (21). С. 115-118.

3. ДБН В.1.3-2:2010, Геодезичні роботи. Міністерство регіонального розвитку та будівництва. Україна. Київ, 2010. URL: https://www.minregion.gov.ua/ wp-content/uploads/2016/04/13_2_2010.pdf (дата звернення: 14.02.2021). 
4. Закон України "Про охорону культурної спадщини". URL: https://zakon.rada.gov.ua/laws/show/1805-14\#Text (дата звернення: 4.02.2021).

5. Інструкція 3 топографічного знімання у масштабах 1:5000, 1:2000, 1:1000 та 1:500 (ГКНTA - 2.04-02-98). URL: https://zakon.rada.gov.ua/laws/ show/z0393-98\#Text (дата звернення: 14.02.2021).

6. Инструкция по нивелированию I, II, III и IV классов. Москва : Недра, 1990.

7. Дишлик О., Марков С. Геодинамічні спостереження за грунтовим масивом та пам'ятками Судацької фортеці. Сучасні досягнення геодезичної науки $i$ виробництва. 2010. Вип. I (19). С. 140-146.

8.Балян А., Ямелинець С., Кубрак О. Особливості виготовлення та закладання центрів геодезичної мережі для спостережень за деформаціями на території Підгорецького монастиря. Сучасні досягнення геодезичної науки та виробництва. Львів : Видавництво Львівської політехніки, 2020. Том 1(39). С. 90-95.

9. Ішутіна Г.С. Оцінювання надійності геодезичної мережі при геомоніторингу забудованих територій. Авторферат. Дніпропетровськ, 2015. URL: $\quad$ http://www.knuba.edu.ua/ukr/wp.content/uploads/2015/10/Ishutina dissertation.pdf (дата звернення: 14.02.2021).

10. Серант О.В., Кубрак О.Д., Ярема Н.П., Батура М.В., Рачок В.І. Особливості побудови геодезичної мережі для розробки відкритих родовищ рудних копалин. Молодий вчений. 2020. № 11. С. 9-14. doi: $10.32839 / 2304-5809 / 2020-11-87-3$

\section{References:}

1. Jamelynecj S., Prystupa O., Balian A., Jamelynecj A. (2017) Stvorennja gheodezychnogho polighonu dlja planovo-vysotnykh sposterezhenj za zsuvamy gruntu i deformacijamy budivelj na terytoriji Pidghorecjkogho monastyrja u Ljvivsjkij oblasti [Creating geodetic polygon for planned high-altitude observations of landslides and deformations of buildings on the territory of the Pidhirtsi monastery in Lviv region]. Modern achievements of geodetic science and production, vol. 1, no. 33 , pp. 61-65.

2. Trevogho I., Ghur'jeva M. (2011) Suchasni centry gheodezychnykh punktiv. Suchasni dosjaghnennja gheodezychnoji nauky ta vyrobnyctva [Modern achievements of geodetic science and production]. Modern achievements of geodetic science and production, vol. 1, no. 21, pp. 115-118.

3. DBN V.1.3-2:2010, Gheodezychni roboty. Ministerstvo reghionaljnogho rozvytku ta budivnyctva [DBN (National construction regulations of Ukraine) V.1.3-2:2010, Geodetic works. Ministry of Regional Development and Construction of Ukraine]. Kyiv, 2010. Retrieved from: https://www.minregion.gov.ua/wp-content/uploads/2016/04/13_2_2010.pdf (accessed 14 February 2021). (in Ukrainian)

4.Zakon Ukrajiny "Pro okhoronu kuljturnoji spadshhyny" [Law of Ukraine "On Protection of Cultural Heritage"]. Retrieved from: https://zakon.rada.gov.ua/ laws/show/1805-14\#Text (accessed 14 February 2021). (in Ukrainian) 
5. Instrukcija $\mathrm{z}$ topoghrafichnogho znimannja u masshtabakh 1:5000, 1:2000, $1: 1000$ ta 1:500 (GhKNTA - 2.04-02-98) [Instruction on topographic surveying at 1:5000, 1:2000, 1:1000 and 1:500 scales (HKNTA - 2.04-02-98)]. Retrieved from: https://zakon.rada.gov.ua/laws/show/z0393-98\#Text (accessed 14 February 2021). (in Ukrainian)

6. Nedra (1990) Ynstrukcyja po nyvelyrovanyju I, II, III y IV klassov [Instruction on levelling procedure of I, II, III and IV classes]. Moscow.

7. Dyshlyk O., Markov S. (2010) Gheodynamichni sposterezhennja za gruntovym masyvom ta pam'jatkamy Sudacjkoji forteci [Geodynamical observation of soil mass and landmarks of Sudak fortress]. Modern achievements of geodetic science and production, vol. 1, no. 19, pp. 140-146.

8. Balian A., Yamelynets S., Kubrak O. (2020) Osoblyvosti vyghotovlennja ta zakladannja centriv gheodezychnoji merezhi dlja sposterezhenj za deformacijamy na terytoriji Pidghorecjkogho monastyrja [Peculiarities of production and set up of geodetic network centres for observation of deformations on the premises of the Pidhoretsk monastery]. Modern achievements of geodetic science and production, vol. 1, no. 39, pp. 90-95.

9. Ishutina Gh. S. (2015) Ocinjuvannja nadijnosti gheodezychnoji merezhi pry gheomonitorynghu zabudovanykh terytorij [Evaluation of the reliability of the geodetic network in geomonitoring of built-up areas]. Avtorferat. Dnepropetrovsk. Retrieved from: http://www.knuba.edu.ua/ukr/wpcontent/uploads/2015/10/ Ishutina_dissertation.pdf (accessed 14 February 2021). (in Ukrainian)

10. Serant O. V., Kubrak O. D, Jarema N. P., Batura M. V., Rachok V. I. (2020) Osoblyvosti pobudovy gheodezychnoji merezhi dlja rozrobky vidkrytykh rodovyshh rudnykh kopalyn [Peculiarities of construction of geodesic network for development of open mineral deposits]. Young scientist, vol. 11, pp. 9-14. doi: $10.32839 / 2304-5809 / 2020-11-87-3$ 